\title{
Managers' Perception of Corruption in Croatia, Serbia and Slovenia
}

\section{Valerija Botric *}

\author{
https://doi.org/10.31297/hkju.20.4.5 \\ UDK 343.352:35.08(497.5:497.1:497.4) \\ 316.32:35.08(497.5:497.1:497.4) \\ Review scientific paper/pregledni znanstveni rad \\ Received/primljeno: 27.04.2020. \\ Accepted / prihvaćeno: 27.11.2020.
}

A comparative analysis of managers' perception of corruption in three post-transition economies based on the World Bank Enterprise Survey data in the 2002-2019 period has been provided in the paper. Results suggest that although the main forms of corruption seem to differ among the countries, within each country there does not seem to be any systematic change during the analysed period. While in Slovenia managers are most likely to acknowledge the existence of grand corruption, petty corruption seems to be more widespread in Croatia and Serbia according to the managers' view. Those who perceive corruption to be higher are also the ones more likely to consider it an obstacle to their business endeavours. The difference is the highest in Croatia, suggesting that additional efforts in reducing corruption would probably be most welcomed by the business sector in that country.

* Valerija Botrić, PhD, the Institute of Economics, Zagreb, Croatia (Ekonomski institut u Zagrebu, Hrvatska, e-mail: vbotric@eizg.hr)

ORCID ID: https://orcid.org/0000-0001-5482-7490 
Keywords: corruption, managers' perception, Croatia, Serbia, Slovenia, comparative analysis

\section{Introduction}

Corruption is a well-researched topic, in particular within the transition economies perceived as having high levels of corruption, frequently attributed to the legacy of the communist system (Sandholtz \& Taagepera, 2007; Borošak \& Šumah, 2018) and the ill-managed privatisation processes (Aidis, Estrin \& Mickiewicz, 2012). This paper is focused on corruption patterns in three post-transition ${ }^{1}$ economies that emerged from the same governing unit - Croatia, Slovenia and Serbia - thereby sharing the initial institutional framework at the beginning of the transition process. The evolution of the countries since has been very different, ${ }^{2}$ thus providing an interesting opportunity to discuss potentially different paths of corruption and its manifestations.

Corruption is notoriously difficult to assess because of its elusive nature. Researchers consequently resort to analysing the perception of corruption, rather than its concealed manifestations. Due to corruption variety, perception is most broadly assessed through a survey of a country's citizens. ${ }^{3}$ The most notable indicator is the Corruption Perception Index. ${ }^{4}$ According to its latest issue

${ }^{1}$ Fink-Hafner and Thomas (1919) summarise different aspects of socioeconomic and political developments that result in different characteristics of the analysed countries.

2 The complexity of the transition process implied that the paths of individual countries from planned to market economies were widely different. In order to assess various aspects of transition, EBRD initiated a set of indicators in 1997 (https://www.ebrd.com/ what-we-do/economic-research-and-data/transition-impact/history). According to the six different indicators monitoring different aspects of transition, Croatia was close to the standards of a market economy in "small-scale privatisation" in 1993, "price liberalisation" in 1992 and "trade and foreign exchange systems" in 1994. Serbia reached the standards in "price liberalisation" in 2001, and "trade and foreign exchange systems" in 2009. Slovenia reached the standards in "small-scale privatisation" as well as "trade and foreign exchange system" in 1993, "price liberalisation" standards in 1998.

${ }^{3}$ I.e. Sekulić (2010) presents results of a survey for the year 2004 showing that $72 \%$ of Croatian citizens believed that most civil servants are involved in corruption.

${ }^{4}$ The selected countries reach unfavourable positions also in other similar rankings; i.e. according to the World Bank Control of Corruption indicator (https://databank.worldbank.org/databases/control-of-corruption), Slovenia's percentile rank for the year 2018 was 80.7, Croatia's 60.1 and Serbia's 41.8. According to the latest data from the Global Corruption Barometer (Global Corruption Barometer 2017 - Transparency.org), 22\% of Serbian 
published for the year 2019, ${ }^{5}$ Slovenia had the least corruption (ranked $35^{\text {th }}$ in the world), followed by Croatia (ranked $63^{\text {rd }}$ ) and Serbia (ranked 91 ${ }^{\text {st }}$ ). Their relative position remained more or less the same throughout 20122019 , even though some other countries in the region did change their relative positions. ${ }^{6}$ Previous studies based on different corruption indicators also portray similar relations between the countries. Wallace and Latcheva (2006) found among the analysed economies in Central and Eastern Europe the highest prevalence of black economy in Serbia and Croatia. Perlić (2016) focuses on comparing Serbia and Croatia through various corruption indicators and finds the two countries similar in many aspects. In the present analysis, the focus is on corruption as an impediment to economic growth, ${ }^{7}$ thus we are primarily interested in the perspective of firm managers. ${ }^{8}$ Contrary to the research focusing on aggregate corruption indicators, the emphasis in the present analysis is on different forms of corruption. Specifically, the main question is whether the managers' perceptions on average differ between the analysed countries when it comes to grand and petty corruption. The former is assessed by the perception of corruption on different levels of government, while the latter by the perception of corruption at the level of an administrative agency or service: tax and customs, business licenses, inspections, utility connections, courts or public education and health facilities. Additionally, different factors contributing to the probability that a firm will engage in petty corruption are explored across the countries. The paper seeks to explore

citizens reported paying a bribe when accessing public services in the last 12 months, $10 \%$ of Croatian and 3\% of Slovenian citizens. The Coppedge et al. (2020) Varieties of Democracy Project provides an extensive list of indicators. According to the political corruption index, Croatia's score in 2019 was 32.1, Serbia's 70.6 and Slovenia's 26.1. At the same time, the public corruption index for Croatia was 40.1, Serbia's 62.9 and Slovenia's 11.5. Although different measures of corruption frequently come under severe criticism, this shows that they do, as also argued by Charron (2016), provide similar evidence.

${ }^{5}$ More at https://www.transparency.org/cpi2019

${ }^{6}$ I.e. during the same period Bosnia and Herzegovina recorded a significant worsening of the relative position, while the Czech Republic recorded a significant improvement.

${ }^{7}$ Although corruption has been considered as an important obstacle to doing business, on an aggregated level there is no perfect correlation between doing business and corruption indicators. Indeed, the World Bank's Doing Business aggregated indicator benchmarked for May 2019 Croatia ranked 51st, Serbia 44th and Slovenia 37th (https:// www.doingbusiness.org/en/rankings). This suggests that microeconomic evidence based on firm-level data is necessary.

8 Investigating managers' perception relies on Lawrence and Lorsch (1967), who suggest that when managers align organisational properties with the properties of their business environment, they are able to secure better firm performance. 
in a comparative analysis the contribution of different forms of corruption as perceived by the business sector.

The paper adopts the following structure. The next section briefly discusses relevant literature. Section three discusses the data and methodology applied in the analysis presented in section four. The last section offers conclusions.

\section{Literature Review}

Although corruption is widely publicly discussed, there is little agreement in the literature on its adequate definition. The most frequently used seems to be the broad definition offered by the World Bank, envisaging corruption as the abuse of public office for private gain (World Bank, 1997). Due to its elusive nature, measuring corruption also attracted significant attention among researchers (Ledeneva, Bratu \& Köker, 2017). Knack (2007) analyses a plethora of surveys created with the intention of measuring corruption, and states that no single corruption measure and no single data source on corruption is most appropriate for all purposes. Heywood (2015) suggests that since the 1990s the dominant mode of measurement has been based on perception, i.e. based on the respondents' perception aggregated indices are created, including the Corruption Perception Index (CPI), Bribe Payers Index (BPI), Global Corruption Barometer, Business Environment and Enterprise Performance Surveys (BEEPS), and the Control of Corruption element in the World Bank Group's Worldwide Governance Indicators (WGI). A detailed critique of the most widely used corruption indicators is offered by Chabova (2017), who concludes that a combination of aggregate corruption indicators is preferable on the country level, while opinion polls are preferable for microanalysis. In addition to methodological concerns related to aggregate corruption indices, the specific wording of the survey questions related to corruption also deserved attention in the literature (Nur-tegin \& Jakee, 2020; Gutmann, Padovano \& Voigt, 2019; Chabova, 2017). The differences occur because of different scopes of social norms across countries, the reluctance of respondents to admit to participating in corruption in experience-formed questions, and the biases in the perception of corruption activities among those who participate in corruptive behaviour $(\mathrm{Cu}-$ ervo-Cazurra, 2016). Gamberoni and his colleagues (2016) suggest that by avoiding direct questioning, careful implementation of adequate inter- 
viewing techniques and an accurate design of survey questions can lead to more accurate reporting of corruption practices by survey respondents. Regardless of the methodological obstacles related to measuring corruption, it remains an important policy issue (Heywood, 2015). The importance of studying corruption stems from the notion that it has a negative impact on economic growth (Mauro, 1995), and decreases the quality of the public sector, as it leads to the loss of public trust and belief in the political system (Karklins, 2005). In general, corruption has a negative ${ }^{9}$ impact on the citizens' life satisfaction (Helliwell, 2006), and the potential to subsequently lead to civil unrest (Brown, Touchton \& Whitford, 2011; Pellegata, 2012).

Varieties of corruption have been categorised into two main types (Elliot, 1997). Low-scale or petty corruption includes a single act of payment in order to gain access to a specific government service. A classic example is bribing local officials in order to receive a specific licence (more quickly). This type of corruption is highly visible to the wider public, because the amount of bribery is usually not set prohibitively high and a large proportion of the population gets in contact with such practices - not only firms, but also citizens who require certain licences or are subject to some forms of inspection. Due to this widespread occurrence, the citizens become accustomed to administrative corruption to the point that it is sometimes argued that "corruption greases the wheel of the economy" (Krammer, 2013). The second type is called grand-scale corruption, taking the form of seizing the law-creating process or doing business via political links in the government (Hellman, Jones \& Kaufmann, 2002). This form, also known as "state-capture", is usually less visible, but the associated typical financial scores are usually higher. It is observed on relatively rare occasions, revealed as government officials' "scandals" frequently within the scope of political opponents' campaigns during the elections. Such events usually cause spikes in the citizens' perception of the corruption level, but their impact on corruption awareness is usually not long-lasting. ${ }^{10}$

9 There is also abundant literature claiming that corruption is beneficial for economic growth, starting from the seminal contributions of Huntington (1968) and Leff (1964). Recent contributions to greasing the wheels include: Bologna and Ross (2015), Dreher and Gassebner (2013), Williams, Martinez-Perez and Kedir (2016). Recent empirical evidence suggests that although some forms of corruption seem to be beneficial to enterprises, there is more evidence in favour of the "sanding the wheels" of economy hypothesis (Nur-tegin \& Jakee, 2020).

${ }^{10}$ Potrafke (2019) documents an increase in corruption perception in pre-election years. 
Even though corruption is a worldwide phenomenon, it has received special attention in transition economies. Shleifer and Vishny (1993) argue that during the post-communist era, government agents started to act more independently in comparison to a one-party system, and this contributed to the spread of corruption. Schneider and Enste (2000) show that rising corruption was correlated with the informalisation of large sectors of the economy and non-transparent privatisation (Godoy \& Stiglitz, 2007); this in turn created increased tax pressure, which subsequently spurred more tax evasion, thus leading to the creation of the vicious circle of corruption. The large and inefficient public sector grew, compelling private agents to grease the wheels of public administration in order to make it more efficient. Moreover, some scholars have argued that the corrupt masses democratically generated new corrupt elites, even when the former communist elites were out of the political arena (Sandholtz \& Taagepera, 2007).

The open question remains whether these corruption-enabling processes maintained their influence in the post-transition period. One of the counteracting actions was attributed to the European Union accession process, as one of the important steps was the ability to ensure good governance conditions. Grubiša (2010) explains how efforts to reduce corruption were related to the EU accession and suggests that among all new Member States, Slovenia had one of the lowest corruption incidences, while Croatian problems with corruption were judged to be serious by EU officials during the accession phase (Bejaković, 2017). Serbia still remains on its EU accession path and the effects of the process are not so pronounced as in the other two economies, although corruption is one of the topics closely monitored (Bogojević \& Skakavac, 2018). There is no guarantee, though, that EU membership itself acts as a counter-corruption measure.

Although corruption has many aspects, its detrimental economic effects are not often studied on the microeconomic level (Ullah, 2020). Firms in corrupt environments frequently engage in such activities, adopting them as a "business as usual" practice (Anand, Ashforr \& Joshi, 2005). In a commercial setting where corruption is commonplace, managers may conclude that such practices are ordinary or even necessary for the operation of the firm (Collins, Uhlenbruck, \& Rodriguez, 2009). This can even contribute to the routinisation of corruptive practices within firms (Vaughan, 1999).

Scholars have not reached conclusions on the impact of such practices on the firm level. On the one hand, corruption requires at least two types 
of additional costs - the amount of informal payment and the time required for dealing with corrupt government officials (Kaufmann, 1997; Svensson, 2005). On the other hand, individual companies may be able to benefit from getting government contracts (Cheung, Rau \& Stouraitis, 2012). Thus, managers can rationalise corruption as another source of competitive advantage or as a mechanism for reducing transaction costs in countries with high levels of regulation.

It has also been found that not all firms are prone to bribery. Svensson (2003) and Fisman and Svensson (2007) stress that bribery practices are industry- and region-specific, while other studies implicate that bribery is related to the firms' size (Safavian, Graham \& Gonzalez-Vega, 2001; Beck, Demirgüc-Kunt \& Levine, 2006), ownership, market orientation, and capabilities (Luo \& Han, 2009). Some even argue that the differences in the bribes paid by firms depend not only on their ability to pay a bribe, but also on their ability to refuse the payment of a bribe (Svensson, 2003). Specific attention in the literature has also been devoted to the role of multinational enterprises (MNE). Initially, stronger inclusion of MNEs in the economic landscapes of transition economies was advocated, because of a rather naive belief that they would transfer their best management practices. But, as Sundaram and Black (1992) suggest, politics is an essential area for international business, so it was soon revealed that MNEs have diverse practices accommodating local business conditions in order to enhance their own competitive positions (Moran, 2006). Since foreign direct investments have been propagated throughout transition economies, and in particular in South-Eastern Europe (Apostolov, 2016), as a major capita ${ }^{11}$ attraction policy, potential differences in corruption perceptions between foreign and domestic managers are interesting.

There is relatively little comparative evidence on corruption for the post-transition countries in the region. Existing studies are usually focused either on providing global conclusions supposed to be valid for a larger group of countries (Gamberoni et al., 2016; Blagojević \& Damijan, 2013; Habiyaremye \& Raymond, 2018), or on an individual country indepth perspective. Previous studies have focused on the overall corruption effects and different forms of corruption have not been explored. In addition to providing a comparative analysis of corruption varieties in three neighbouring countries, the main contribution of the paper is in the attempt to provide an evolutionary perspective across a period of almost

${ }^{11}$ Firms exposed to corruption are also financially constrained (Ullah, 2020). 
two decades. Since the focus is on managers' perspectives, the results are important from the point of view of competitiveness of the analysed economies. Additionally, the comparative in-depth analysis of the most recent data provides an opportunity to offer policy recommendations.

\section{Data and Methodology}

In order to be able to adopt a comparative approach, the World Bank Enterprise Survey data have been used ${ }^{12}$ due to their relatively large coverage of corruption-related questions ${ }^{13}$ comparable across the countries in the sample. The Survey itself has evolved through waves, thus the questionnaire and some of the variables subsequently used in the analysis are not directly comparable through time. In order to maintain comparability, the presentation of the results is governed by the largest possible intersection of the dataset. First of all, the results are restricted to the waves of 2002, 2005, 2013 and 2019. This representation also allows for a discussion on the possible impact of the global economy's financial crisis ${ }^{14}$ on the results, because the first two waves clearly present the pre-crisis period, while the waves of 2013 and 2019 represent the post-crisis period.

To address the issue of grand corruption, the incidence of informal payment to government officials is analysed..$^{15}$ Corruption on three levels of

12 Individual firm level data are available for download at https://www.enterprisesurveys.org/. The Survey, also referred to as the Business Environment and Enterprise Performance Survey (BEEPS), has evolved through different waves, for the years 1999, 2002, 2005, 2007, 2009, 2012 and 2019. The website, along with the data, contains all questionnaires and sample information data. Respondents of the Survey are business owners and top managers, in order to impose accountability of the answers provided. Not all the countries were included in all the waves, and the 2019 Survey results are not yet available for all participating countries. The number of firms participating in the analysed countries is presented in Appendix Table A1.

${ }^{13}$ Knack (2007) argues that one of the advantages of the BEEPS for measuring corruption is that it enables exploring different forms across various functions of government.

14 Studies have shown that the managers' perceptions of their firms' financial constraints influence the decision to bribe (Martin et al., 2007). Due to the large financial constraints on the financial markets during the global financial crisis of 2008-2009, in particular for post-transition economies whose financial systems are judged as particularly vulnerable, this point is important to explore.

15 The question asks about the respondent's general acquaintance with such activities - "it is often said that firms make gifts or informal payments to public officials to gain advantages in the drafting of laws, decrees, regulations or other binding government deci- 
government has been addressed through payments, gifts or exchange of favours with:

- parliamentarians to affect their votes,

- national government officials to affect the content of government decrees,

- local or regional government officials to affect their votes or the content of local or regional decrees.

Next, the size and form of informal payments, as well as the firm's ties to the government sector, have been assessed. The assumption of the latter is that the firms regularly doing business with the government sector are more in a position to observe typical behaviour of government officials and/or participate themselves in informal payments. In case of a corrupt environment, the efficiency of public administration is also lower. The questionnaire, however, did not maintain the same focus on informal payment occurrence in the pre-crisis and post-crisis period. In the pre-crisis period, the focus was on capturing the size of the informal sector in transition economies, still perceived to largely govern economic affairs. With regard to the issue of whether firms have stronger links with the government sector, there are two variables:

- In the pre-crisis period, the question was: "What percentage of your domestic sales are to the government or government agencies (excluding state-owned enterprises)?" For the empirical analysis, a dummy variable has been created that takes value 1 if the percentage is larger than zero.

- In the post-crisis period, the question was: "Over the last year, has this establishment secured or attempted to secure a government contract?" In this case a dummy variable has been created that takes value 1 if the respondents provided a positive answer to the question.

Next, the question on the typical amount paid to the government for securing a contract was explored. The average values of respondents who reported a positive value for the corresponding survey question ${ }^{16}$ is provided in the empirical section.

sions". Respondents were asked whether such practices have a direct impact on their firm by using a scale from 1 (no impact) to 5 (very major impact), and the options are not mutually exclusive. A dummy variable has been created that takes value 1 if the respondent estimated major or very major impact.

16 "When firms in your industry do business with the government, how much of the contract value would be typically paid in additional or unofficial payments/gifts to secure the contract?" 
Petty corruption is captured through the investigation of the forms of activities, where the respondents reported either perceiving or experiencing informal payments. In the pre-crisis period, it was assumed that firms would be reluctant to answer directly to the question on informal practices if they themselves had been engaged in such activities. So, the question was formed indirectly. ${ }^{17}$

In the post-crisis period, it is possible to directly explore if the firms have engaged in certain activities and whether they expected or requested for a counter service in that case. ${ }^{18}$ The literature claims that there are important differences between the perceived and experienced corruption (Gutmann, Padovano \& Voigt, 2019), so the answers are not comparable to the pre-crisis period even though they refer to similar activities. It is assumed that the respondents with direct corruption experience tend to perceive corruption to be higher in general, than the respondents who did not have personal experience with corruptive behaviour (Charron, 2016). Another important question is whether there are differences between domestically owned firms and those with at least some foreign capital in the ownership structure. Although foreign management practices have been frequently advocated as important for the future development of firms in transition $(\mathrm{Fu}, 2012)$, the literature also suggests that multinational corporations engage in bribing local officials, thus taking advantage of looser governance standards in the countries where anti-corruption laws are less likely to be enforced than in their home markets (Moran, 2006). Indeed, some studies have found that foreign firms are almost twice as likely to be engaged in grand corruption as domestic firms (Hellman, Jones \& Kaufmann, 2002).

In order to gain deeper insight, an investigation was carried out into the differences in the factors contributing to a firm's probability to engage in petty corruption. Since the dependent variable is a binary variable taking value 1 if a manager reported participation in any form of petty corruption during the year 2019, estimates were performed using the probit model. The choice of independent variables was guided by the literature.

17 "Thinking now of unofficial payments/gifts that a firm like yours would make in a given year, could you please tell me how often would they make payments/gifts for the following purposes ... ?" Since the respondents could answer on a 6-point Likert scale (ranging from 1-never to 6-always), a dummy variable has been created that takes value 1 if the answer was 5-usually or 6-always.

18 Specifically, respondents were asked whether an informal gift or payment was expected or requested in relation to a specific activity. 
Personal characteristics of the manager ${ }^{19}$ were considered: gender (Hanousek, Shamshur \& Trel, 2019) and experience (Collins, Uhlenbruck \& Rodriguez, 2009). Firm characteristics include age (Collins, Uhlenbruck \& Rodriguez, 2009), the owners' gender (Wellalage, Locke \& Samujh, 2019), size (Safavian, Graham \& Gonzalez-Vega, 2001; Beck, DemirgücKunt \& Levine, 2006), sector (Svensson, 2003), ownership (Luo \& Han, 2009; Moran, 2006), whether the firm is an innovator (Habiyaremye \& Raymond, 2018), or exporter (de Jong \& Bohmans, 2011). Variables depicting enabling corruption situations include: time dealing with government officials (Svensson, 2005), whether a person from the firm's governing structures has been elected or appointed to a political position (Collins, Uhlenbruck \& Rodriguez, 2009), whether the firm has a government contract (Cheung, Rau \& Stouraitis, 2012), and whether it competes against informal competitors (Iriyama, Kishore \& Talukdar, 2016). The estimates were performed for each country separately, but following the same procedure.

Figure 1: Estimation strategy representation

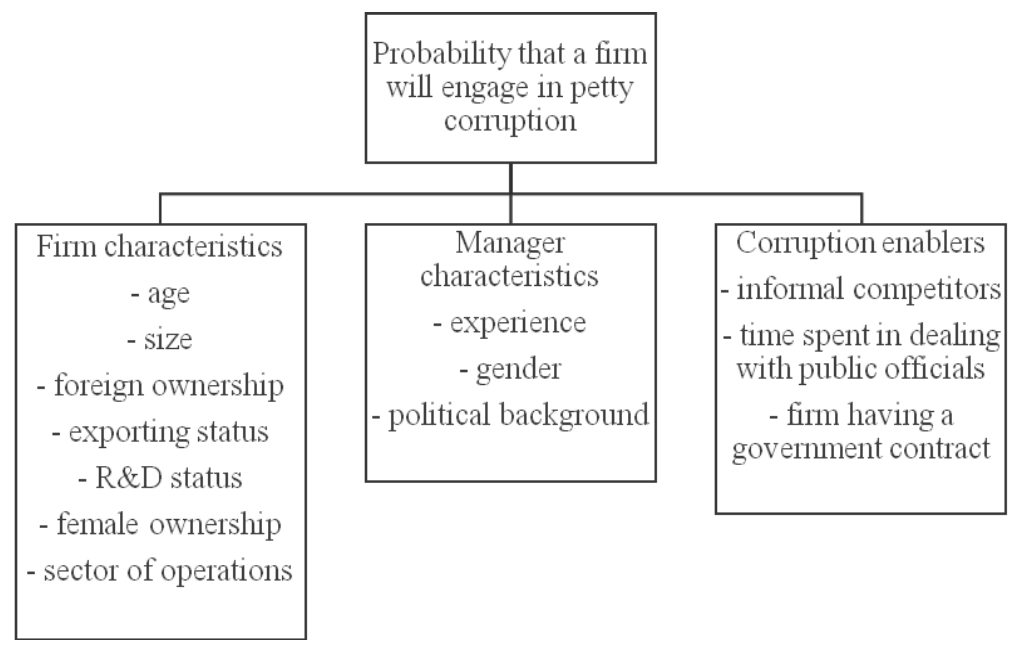

Source: Author's representation.

19 Literature also recognises some other personal characteristics that might influence the probability of participating in corruptive activity; i.e., Mocan (2008) lists age, marital status, labour market activity, wealth, education, gender, and the location of the residence of the individual. However, such data on respondents are not available in the Enterprise Survey. 
Based on the definition of variables presented in this section, the next section provides comparative evidence for Croatia, Slovenia and Serbia.

\section{Results and Discussion}

The analysis starts with examining the relationship between firms and the government sector, with a focus on the role of foreign firms. Differences in perceptions of corruption between the managers of firms which are completely domestically owned and those that have at least a certain percentage of foreign ownership are presented in Figure 2.

Figure 2: Percentage of firms doing business with the government

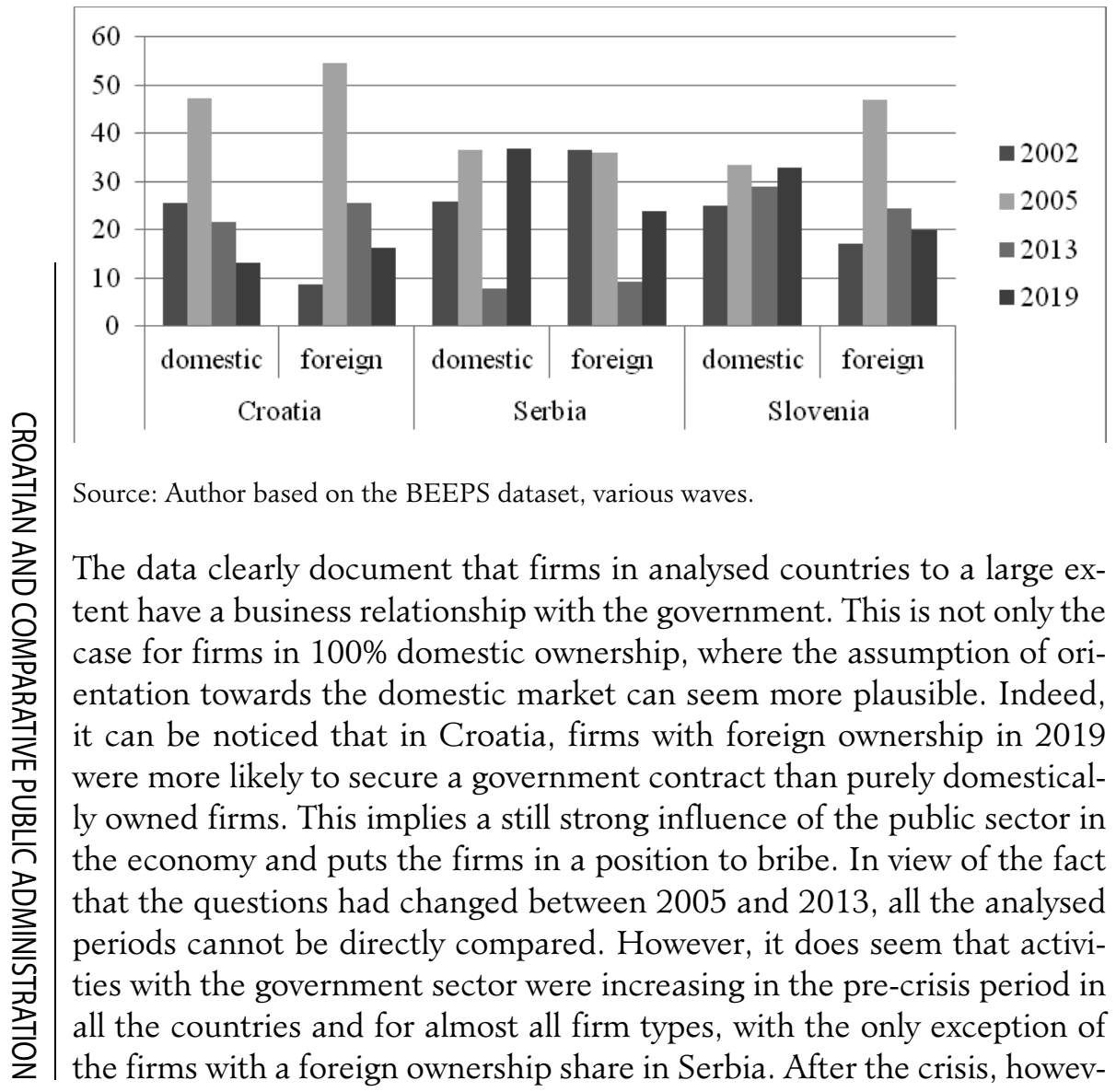


er, business activities with the government sector decreased for Croatian firms and foreign-owned firms in Slovenia. On the contrary, they slightly increased for the domestic firms in Slovenia and very strongly increased for all firms in Serbia. ${ }^{20}$ While dealing with the government puts firms in a position to observe informal practices, it also puts them in a position to assess the extent of the informal payment when dealing with the government sector, which is depicted in Figure 3.

Figure 3: Perceived percentage of contract value in the form of informal payment

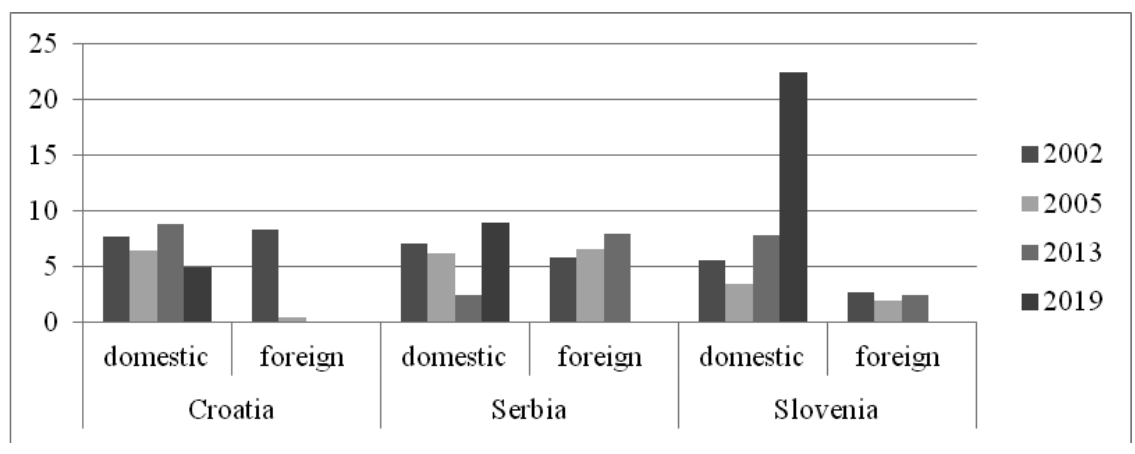

Source: Author based on the BEEPS dataset, various waves.

Here the respondents were asked to report the typical value of informal payment in their line of business, not their personal experience. It is believed that such answers are more likely to be accurate, as respondents might be reluctant to self-report illegal activities. Also, the data in Figure 3 present the averages of provided positive answers, ${ }^{21}$ as it is believed that those respondents did have some information to share in comparison to those who reported zero values or did not respond to the question. Due to this approach, the number of answers is relatively small and the average is under the strong influence of outliers. Nevertheless, some insight can be gained. It can be noticed that in all the countries foreign firms did not provide information for the year 2019, and in Croatia also for 2013. This does not necessarily imply that they are not aware of any informal pay-

${ }^{20}$ Ivanović-Djukić and colleagues (2019), based on a survey covering 250 Serbian entrepreneurs in 2015 , suggest that $60 \%$ resorted to some form of corruption activity when starting their business. Table A2.

${ }^{21}$ The range of provided answers to this specific question is provided in Appendix 
ment, but that they may have simply decided not to share the information. It is also interesting to note that the estimated percentages by domestic firms in Croatia and Serbia were fairly similar in the pre-crisis period, and it also seems that in 2013 domestic firms in Croatia and Slovenia shared impressions of the size of the informal payment necessary to secure a government contract. Such cross-country similarities suggest that respondents are more likely to accurately assess the value (approximately $5-8 \%$ of the contract value). However, in general there does not seem to be any systematic trend in the decrease or increase of the informal payments related to ensuring a government contract for domestic or foreign firms.

We turn attention to the question of whether those who obtain a government contract perceive corruption to be a higher obstacle to their business activity. The data in Figure 4 provide expected results - those who do business with the government believe that corruption is a more serious problem for their firm; the difference is the highest in Croatia, followed by Slovenia, while in Serbia the difference is relatively small. ${ }^{22}$ Such results imply that additional efforts in reducing corruption would probably be most welcomed by the business sector in Croatia.

Figure 4: Corruption as an obstacle to business activity if having a contract with the public sector, 2019

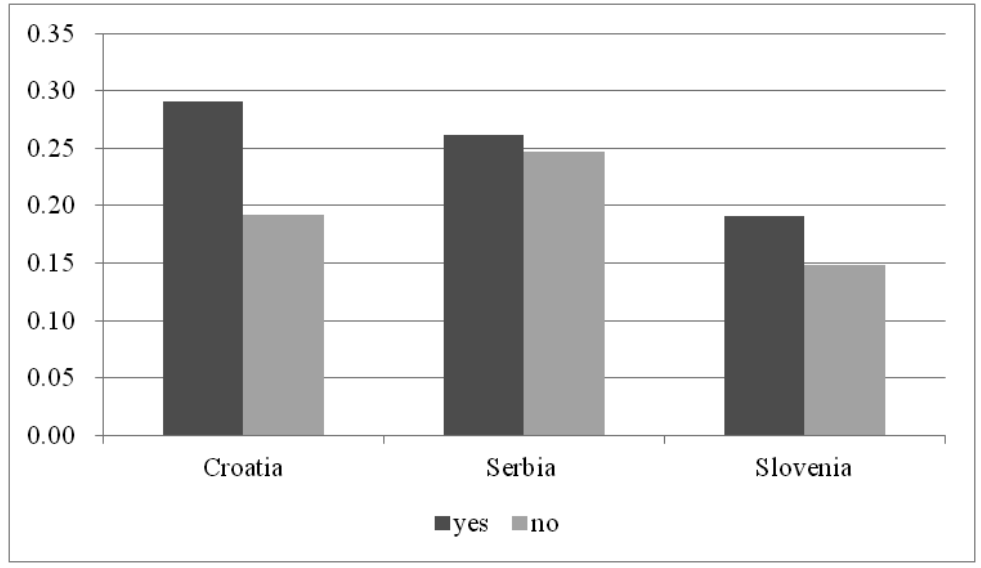

Source: Author based on BEEPS 2019.

22 This could be related to the argument that corruption is systematic in Serbia and "bribery has become a necessary condition for even the smallest business enterprise" (Bjelalac \& Bingulac, 2016, p. 212). 
The subsequent analysis is devoted to exploring the differences in the forms of petty corruption across the countries. Similar to the overall citizens' corruption perception depicted through the Corruption Perception Index, the managers' perception reveals that Serbia had the highest perceived corruption incidence, while Slovenia the lowest (Figure 5). In 2002, managers in Croatia and Serbia perceived that the highest likelihood of corruption was related to obtaining a government contract, while those in Slovenia perceived that it was related to obtaining a business licence. In 2005, Serbian and Slovenian managers maintained their opinion, although Slovenian managers attributed a similar likelihood also to the activities related to buildings and environmental inspections, as well as the legislative process. The latter also attracted attention of Croatian managers as being the most likely candidate for corruptive activities in 2005.

Figure 5: Cross-country comparison of informal payment in different economic activities, pre-crisis period

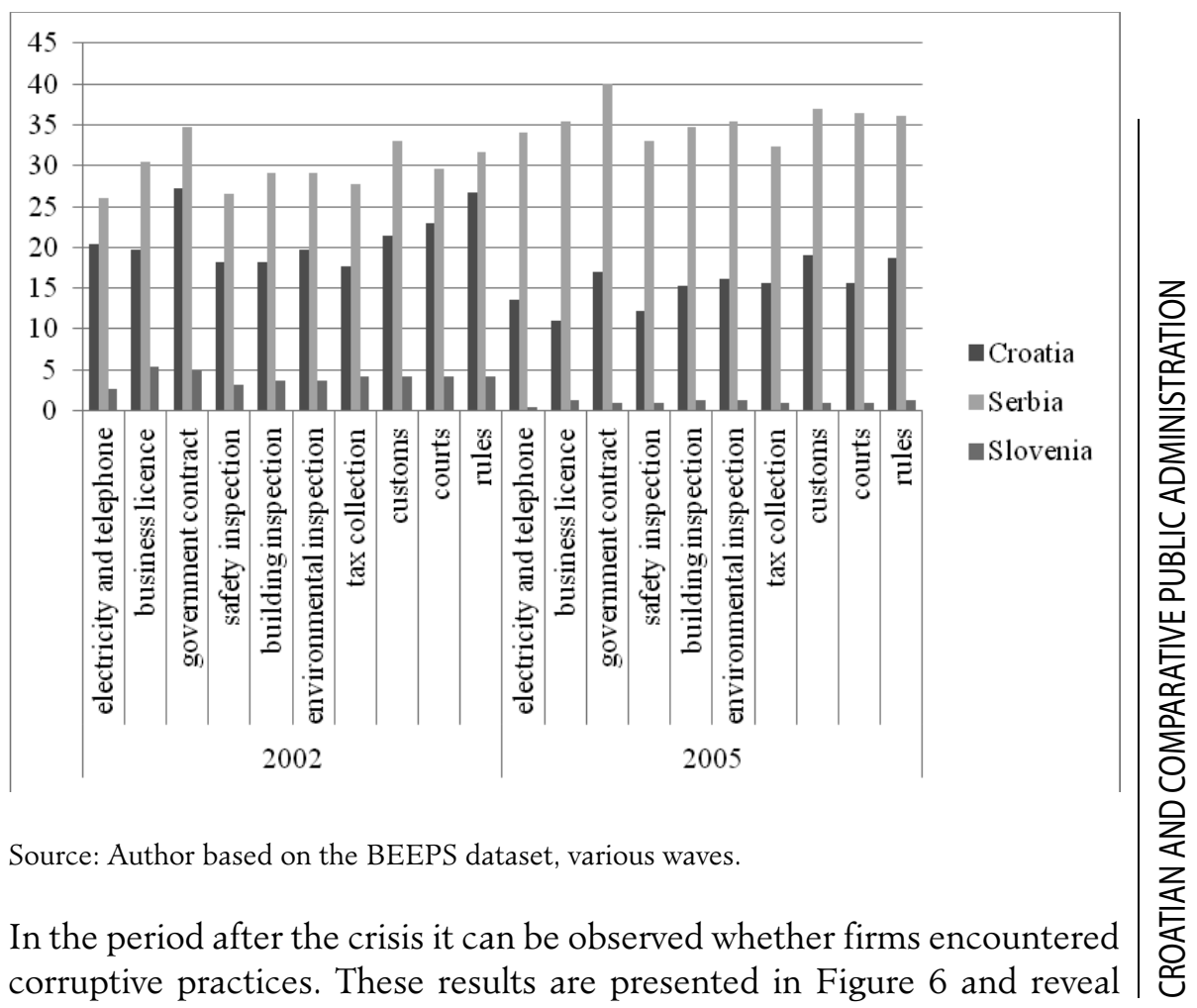


the answers of those respondents who participated in a certain activity where informal practices occur. ${ }^{23}$ Here the data also show that Serbia has the highest perception of the prevalence of informal payments, while Slovenia the lowest. In case of Serbia, ${ }^{24}$ in 2013 the construction sector was the most affected, while in 2019 import licensing took the lead. In case of Croatia, ${ }^{25}$ obtaining operating licences seems to be the activity where firm managers reported the highest incidence of informal payment. The relatively high occurrence of informal payments related to the water sector might be surprising for Slovenia in 2013, and it was not sustained in 2019, when receiving an operating licence became the major activity, followed by obtaining a connection to the electricity grid. It has to be borne in mind that some of the services reported here (such as water or electricity) are still to a large extent provided by state-owned enterprises, although to a different extent in the analysed countries due to the different stages of the market liberalisation process. However, certain services are directly related to the activities of the public officials, and subsequently these results show that in all three countries corruption was still present at least in some form.

In order to gain more insight into the factors contributing to the persistence of petty corruption, we estimated a probit model with the dependent variable taking value 1 if a firm participated in any of the above mentioned forms of petty corruption in 2019.26 The marginal effects of probit estimates are presented in Table 1, while probit estimates are given in Table A3 in the Appendix.

${ }^{23}$ I.e., the data includes the respondent's experience of informal payment for electricity connection only if that respondent applied for a connection to the electricity grid.

${ }^{24}$ Ivanović-Djukić and colleagues (2019) suggest that petty corruption (mostly taking different forms of bribery) is widespread in Serbia. They specifically suggest corruption related to obtaining permits for building construction and obtaining an electricity connection when starting a new business.

25 Glavinja, Cerić and Nahod (2017) focus on the construction sector in Croatia and report that $90 \%$ of their 107 survey respondents believe that corruption in the construction sector is very frequent. Respondents also believe that the pre-qualification and tendering phase and the construction project execution phase are most susceptible to corruption. Furthermore, $76.9 \%$ of respondents did not report any changes in dealing with corruption since EU accession.

${ }^{26}$ For that year, $14.85 \%$ of respondents in Croatia reported participating in at least one of the petty corruption activities, $6.37 \%$ of respondents in Serbia, and $0.97 \%$ of respondents in Slovenia. 
Figure 6: Cross-country comparison of informal payment in different economic activities, post-crisis period

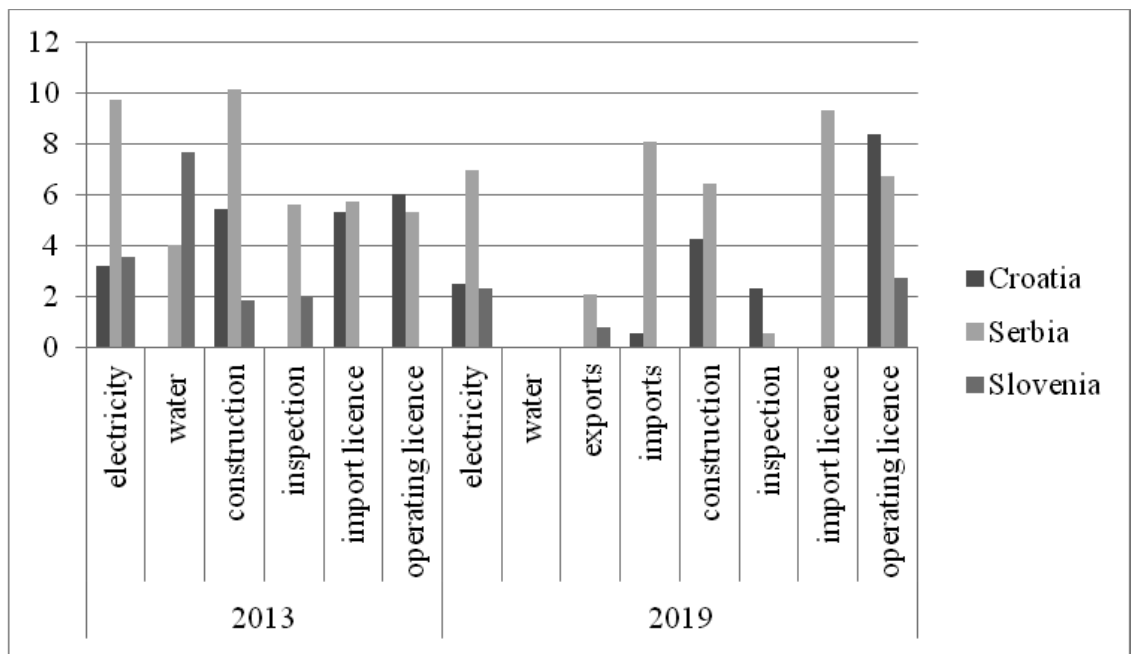

Source: Author based on BEEPS dataset, various waves.

Table 1: Probability of a firm engaging in petty corruption, marginal effects, 2019

\begin{tabular}{|l|l|l|l|}
\hline Variables & Croatia & Serbia & Slovenia \\
\hline Firm age & $\begin{array}{l}-0.000264 \\
(0.000239)\end{array}$ & $\begin{array}{l}0.000349 \\
(0.000402)\end{array}$ & $\begin{array}{l}-0.000143 \\
(0.000222)\end{array}$ \\
\hline \multicolumn{2}{|l|}{} \\
\hline Firm size (vs. medium) & -0.000992 & $-0.0431^{*}$ & -0.00238 \\
\hline -small & $(0.00294)$ & $(0.0233)$ & $(0.0124)$ \\
\hline -large & -0.00313 & $-0.0460^{*}$ & 0.0315 \\
& $(0.00399)$ & $(0.0256)$ & $(0.0250)$ \\
\hline Firm with foreign ownership & - & -0.00208 & 0.0208 \\
& & $(0.0379)$ & $(0.0171)$ \\
\hline Exporter & -0.00202 & $\begin{array}{l}0.0476 \\
(0.0311)\end{array}$ & $\begin{array}{l}-0.0336 \\
(0.0213)\end{array}$ \\
\hline Firm investing in R\&D & $(0.00508)$ & -0.0145 & 0.00191 \\
& 0.0477 & $(0.0272)$ & $(0.00848)$ \\
\hline
\end{tabular}




\begin{tabular}{|c|c|c|c|}
\hline Manager's experience & $\begin{array}{l}-0.00008 \\
(0.000117)\end{array}$ & $\begin{array}{l}0.000268 \\
(0.000996)\end{array}$ & $\begin{array}{l}-0.000940 \\
(0.000849)\end{array}$ \\
\hline Firm with female owners & $\begin{array}{l}-0.00007 \\
(0.00310)\end{array}$ & $\begin{array}{l}0.0212 \\
(0.0297)\end{array}$ & $\begin{array}{l}0.00528 \\
(0.0155)\end{array}$ \\
\hline Firm with a female manager & - & $\begin{array}{l}0.0166 \\
(0.0351)\end{array}$ & - \\
\hline \multicolumn{4}{|l|}{ Sector (vs. manufacturing) } \\
\hline -retail & $\begin{array}{l}-0.00132 \\
(0.00508)\end{array}$ & $\begin{array}{l}0.0720 \\
(0.0519)\end{array}$ & - \\
\hline -wholesale & $\begin{array}{l}0.0112 \\
(0.0230)\end{array}$ & $\begin{array}{l}0.152^{*} \\
(0.0907)\end{array}$ & - \\
\hline -construction & $\begin{array}{l}-0.00143 \\
(0.00464)\end{array}$ & $\begin{array}{l}0.139 \\
(0.0992)\end{array}$ & - \\
\hline -service & - & $\begin{array}{l}0.0526 \\
(0.0654)\end{array}$ & $\begin{array}{l}0.0159 \\
(0.0175)\end{array}$ \\
\hline $\begin{array}{l}\text { Firm having informal competi- } \\
\text { tors }\end{array}$ & $\begin{array}{l}0.0455 \\
(0.0319)\end{array}$ & $\begin{array}{l}0.0228 \\
(0.0257)\end{array}$ & - \\
\hline $\begin{array}{l}\text { Manager's time dealing with } \\
\text { public officials }\end{array}$ & $\begin{array}{l}0.000202 \\
(0.000147)\end{array}$ & $\begin{array}{l}0.00118 \\
(0.000864)\end{array}$ & $\begin{array}{l}-0.000210 \\
(0.000350)\end{array}$ \\
\hline $\begin{array}{l}\text { Firm with a government con- } \\
\text { tract }\end{array}$ & $\begin{array}{l}-0.00356 \\
(0.00266)\end{array}$ & $\begin{array}{l}0.00802 \\
(0.0284)\end{array}$ & $\begin{array}{l}0.0107 \\
(0.0151)\end{array}$ \\
\hline $\begin{array}{l}\text { Firm manager politically elected } \\
\text { or appointed }\end{array}$ & $\begin{array}{l}0.225^{*} \\
(0.125)\end{array}$ & $\begin{array}{l}0.0247 \\
(0.0748)\end{array}$ & - \\
\hline Observations & 220 & 296 & 146 \\
\hline Pseudo R ${ }^{2}$ & 0.335 & 0.0971 & 0.183 \\
\hline
\end{tabular}

Source: Author's estimates based on BEEPS 2019.

Robust standard errors are given in parentheses. ${ }^{* *}$ denotes significance at $1 \%,{ }^{* *}$ at $5 \%$ and ${ }^{*}$ at $10 \%$. Marginal effects are evaluated at the mean of the sample data. The marginal effect of the specific variable is expressed as percentage point change from this level of the predicted probability of engaging in petty corruption at the mean of the data. For dummy variables, the marginal effect represents the change in the probability of petty corruption for firms with and without that characteristic, holding other characteristics constant at the same time. 
Estimates have identified relatively few significant predictors for firms to engage in petty corruption. In case of Croatia, a significant predictor for a firm to engage in petty corruption is if the owner, CEO, top manager, or any of the board members of the firm have ever been elected or appointed to a political position. This shows that political ties in Croatia persist in maintaining the corruptive environment, which is an important result. This result is particularly striking since the fully state-owned enterprises ${ }^{27}$ are not included in the BEEPS survey. The importance of political connections for a business activity is probably even more widespread than it is possible to document with the data. In case of Serbia, both small and large firms are more likely to engage in petty corruption than medium-size firms. Also in case of Serbia, the wholesale sector seems to be more prone to petty corruption than the manufacturing sector.

Finally, we explore whether those who experienced a form of petty corruption are more or less prone to claim that corruption creates an important obstacle to their business. The results are presented in Figure 7. In Croatia and Serbia, the situation is similar to the case when an enterprise had a government contract (Figure 4): those who did have experience with petty corruption are more likely to claim that corruption creates an important obstacle to their business activity. The difference is once again the largest in Croatia, implying that the business community in Croatia is most likely to welcome attempts to reduce corruption. Interestingly, the same findings have not been confirmed for Slovenia. Such a result is probably related to the relatively small occurrence of petty corruption forms in Slovenia (Figure 6): since corruption already is at relatively low levels, the business community in general does not perceive it to be an important obstacle to their activities.

27 Recent newspaper headlines in Croatia report of an ongoing investigation involving a state-owned enterprise director, a city mayor and an entrepreneur as the main actors in possible corruption related to public procurement. More at https://www.tportal.hr/vijesti/clanak/policija-privela-predsjednika-uprave-janafa-i-gradonacelnika-velike-gorice-20200917. 
Figure 7: Corruption as an obstacle to business activity if experiencing petty corruption, 2019

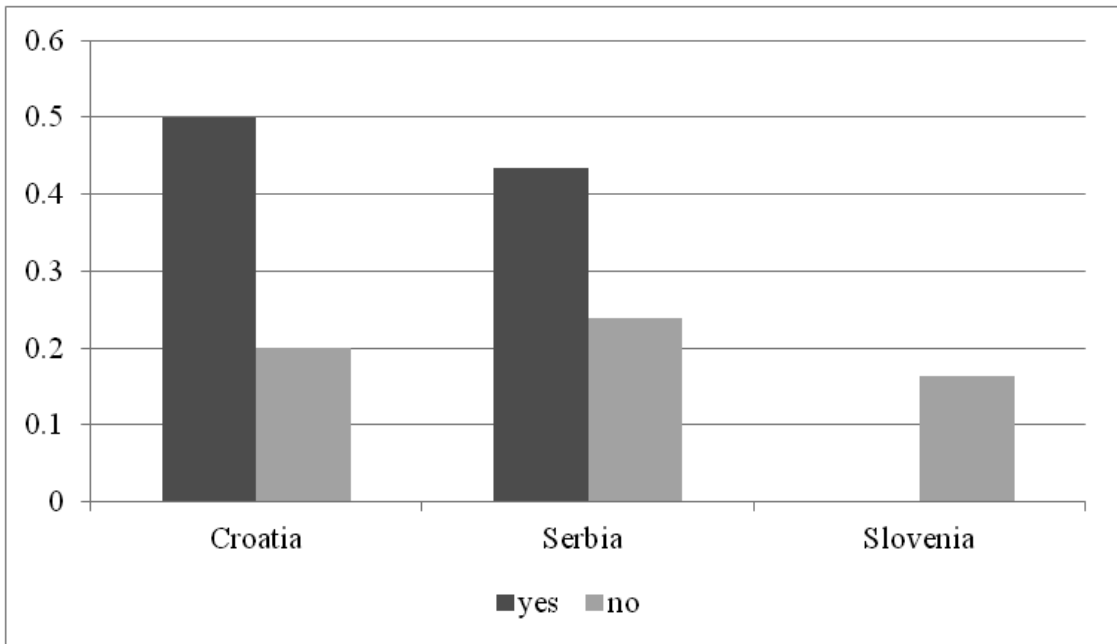

Source: Author based on BEEPS 2019.

This overview has suggested that regardless of the overall size of the informal sector in the analysed countries, from the policy perspective it is of utmost importance to track the most recent forms of petty corruption in order to be able to design specific policy measures to counteract such activities. It is clearly evident that the predominant activities in which petty corruption is perceived by the business sector change through time. Another important reason can be found in previous studies. Habiyaremye and Raymond (2018) analyse the grand and petty corruption's different impact on innovation in the transition economies of Eastern Europe and Central Asia. They somewhat surprisingly find that petty corruption of foreign firms tends to foster major innovations. On the contrary, domestic firms' involvement in petty corruption appears to be detrimental to investment in research and development and introduction of improved products and services, but not to major innovation. This shows that the perception of corruption plays a significant role in reducing innovation and subsequently economic growth. Thus, petty corruption should not be considered as business as usual necessary to grease the wheels of the economy, but rather every effort should be made to encourage its reduction.

Finally, the differences in grand corruption varieties are presented across three analysed countries in the year 2019. The data in Figure 8 show that 
Croatia has the lowest perceived grand corruption. ${ }^{28}$ Contrary to expectations, Slovenia is the country with the highest perceived grand corruption. So, even though the general perception of corruption in Slovenia is relatively low, as well as the petty corruption perceived by the business sector, corruption at the highest levels of government suggests a different picture. This is somewhat contrary to the results presented by Wadsworth, Wheat and Swartz (2012), who provide a comparative analysis based on the same Survey (BEEPS) for the years 2002 and 2005, and suggest that firms in Slovenia perceive the lowest impact on their business from unofficial payments or other benefits to parliamentarians to affect their votes. The findings presented here are more in line with Borošak and Šumah's (2018) argument that "white-collar corruption" has been increasing in Slovenia in the more recent period.

One of the reasons for such potentially contradictory results is that a relatively small share of respondents answer this question. However, this does not mean that we can discard the findings easily. The relatively small percentages of firms reporting corruption do not necessarily mean that the extent of corruption is also small. It could be the case that relatively few enterprises have access to government officials and/or large influence on public officials. As discussed earlier, grand corruption is relatively less visible to the wider public. It might also be the case that the sample was not able to capture the most relevant firms to disclose these practices in all the countries, and it could also be the case that the managers who participated in the Survey decided to respond strategically. An interesting study by Popova and Post (2018) relies on the comparison of indictments of ministers for the act of corruption and actually did not find evidence that EU membership, existence of specialised anti-corruption prosecution or a more independent judiciary raises the profile of grand corruption. According to their findings, Croatia ${ }^{29}$ took the middle position in indicting its ministers during the 2000-2012 period, but had a relatively high conviction rate.

28 According to the Balkan Barometer for the year 2015, the population in Croatia to a larger extent than the population in Serbia believed that corruption is widespread among national and local politicians (Sotiropoulos, 2017). Vuković (2017) analyses corruption on the local level in Croatia and suggests that the reason why voters do not seem to punish corruption can be attributed to the selectorate theory, i.e. adverse effect of small winning coalitions on corruption.

29 In comparison to Bulgaria, Czech Republic, North Macedonia, Poland, Romania and Slovakia. 
Figure 8: Grand corruption forms, 2019

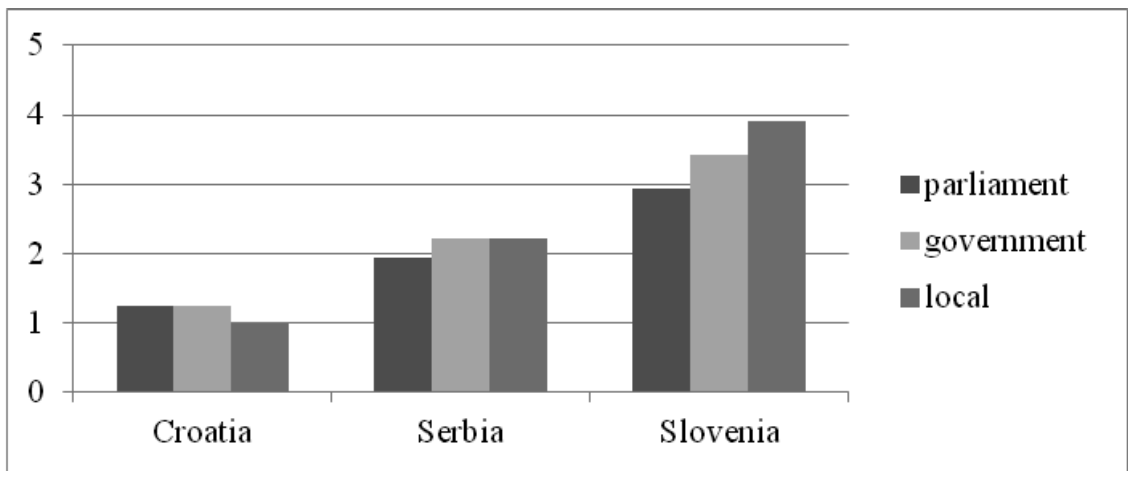

Source: Author based on BEEPS 2019.

Previous studies have found that grand corruption is also detrimental to business endeavours in general. Habiyaremye and Raymond (2018) show that grand corruption decreases the propensity of firms to conduct research and development and to bring new products and services on the market. Thus, it has the possibility to adversely affect potentially the most propulsive segment of the economy, thereby reducing long-term growth prospects. Although some find that grand corruption has the possibility to increase the revenues of a company, thus making it an important activity for the management, it is also important to notice that any type of corruption acts as a kind of tax, by making demand on the time the firm managers spend in dealing with government officials.

\section{Conclusion}

The paper addresses corruption varieties in Croatia, Slovenia and Serbia, with the main focus on whether the countries have developed specific corruption patterns unique to their own economic and political environment. The analysis relies on the World Bank Enterprise Survey data, thereby being based on the managers' perspective on corruption practices. The Survey enables gaining an important comparative insight into the corruption from the business sector perspective. The research presented is focused on the differences between petty (corruption practices in an administrative agency or service) and grand corruption (corruption on different levels of government) in the analysed economies. Detecting specific forms of corruption in a society provides for better targeting of policy measures. 
The analysis has established that both foreign and domestically owned firms did business with the government sector throughout the analysed 2002-2019 period, putting them into a position to at least observe informal payments. However, towards the end of the period, foreign firms refrain from making such statements. Domestic firms, however, report similar estimates of approximately $5-8 \%$ of the contract value being paid to ensure a government contract. The analysis has confirmed that in the analysed economies, the government sector is still important even in the post-transition period. In dealings with the government sector, the business sector seems to frequently encounter corruptive practices. A general policy recommendation would be to decrease the role of government to the regulatory role and to further support the development of entrepreneurship. However, a more specific policy recommendation would be to monitor public procurement more closely in all analysed countries.

The firms which obtain a contract with the government sector perceive corruption to be a higher obstacle to their business activity in all the countries, with the highest difference in Croatia, and the lowest in Serbia. The same result is for those who experience petty corruption - they are more likely to claim that corruption impedes their business endeavours, again with the highest difference in Croatia. Such results imply that additional efforts in reducing corruption, although important for all analysed countries, would probably be most welcomed by the business sector in Croatia. However, from this result a general policy recommendation emerges that efforts to reduce corruption should be kept in focus, regardless of the potentially low perceived level of corruption. The benefits through increased business activity and improved competitiveness are expected to have a wider positive economic impact in all three countries.

Although the main forms of corruption seem to differ among the countries, within each country there does not seem to be any systematic change in the forms of corruption. While in Slovenia managers are most likely to notice grand corruption, petty corruption seems to be more widespread in Croatia and Serbia. In Slovenia and Serbia, respondents seem to recognise a strong corruptive potential of the local government level, while contrary to the general perception, managers in Croatia are less likely to point to local politicians. This does not imply that the level of grand corruption is lower in Croatia, but is probably more related to the fact that Croatia is still a highly centralised economy, and the sources of political power and influence can be found on the national level. Another interesting finding in the case of Croatia is that the managers' political ties obtained during their previous political careers are a strong predictor for engaging in petty 
corruption. While breaking political connections might be relatively hard, introducing more efficient systems of monitoring public administration officials could be a more viable policy option.

From the policy perspective, it is of utmost importance to track the most recent forms of petty corruption, so the implementation of anti-corruption activities can target specific public sector domains. The analysis has revealed such domains for the year 2019. In the Croatian and Slovenian case, additional efforts are expected in connection with the activities related to obtaining an operating licence; in case of Serbia, increased efforts related to preventing corruption in import licencing. Based on the most recent survey results, specific awareness raising campaigns can be organised through employers' associations in order to deter future corruptive practices in specific public administration areas.

Limitations of the present study stem from the fact that it relies on the quality of the data source used. While there is no doubt that the survey has been carried out with the highest standards, the potential strategic answering by the respondent can hardly be avoided when it comes to such an elusive phenomenon as corruption. Thus, research results should not be the only source to determine the direction of policy actions, but should complement the regular activities of institutions responsible for preventing corruptive activity in each country. This can be particularly burdensome as corruption practices are sometimes also deeply rooted in the business culture.

Another disadvantage is that the analysis is restricted to the predetermined set of questions (predominately focused on the firm-government relationship), thus potentially disabling a deeper analysis of a specific phenomenon. A possible remedy could be to supplement the results with another similar survey that would focus on questions specific to the corruption practices of the analysed countries.

\section{References}

Aidis, R., Estrin, S., \& Mickiewicz, T. M. (2012). Size matters: Entrepreneurial entry and government. Small Business Economics, 39(1), 119-139, https://doi. org/10.1007/s11187-010-9299-y

Anand, V., Ashforr, B. E., \& Joshi, M. (2005). Business as usual: The acceptance and perpetuation of corruption in organizations. The Academy of Management Executive, 19(4), 9-23, https://doi.org/10.5465/ame.2005.19417904 
Apostolov, M. (2016). The role of foreign direct investments in Southeastern Europe. Revue d'Études Comparatives Est-Ouest, 47(3), 45-82.

Beck, T., Demirgüç-Kunt, A., \& Levine, R. (2006). Bank supervision and corruption in Lending. Journal of Monetary Economics, 53(8), 2131-2163, https://doi. org/10.1016/j.jmoneco.2005.10.014

Bejaković, P. (2017). Corruption and economic development: The case of Croatia. In J. Ateljević \& Z. Borović (Eds.), Economic development and entrepreneurship in transition economies: Is free trade working for transitional and developing economies? (pp. 21-31). Banja Luka, Bosnia and Herzegovina: Faculty of Economics, University of Banja Luka.

Bjelalac, Ž., \& Bingulac, N. (2016). Impact of corruption on the process of Eurointegration of Serbia. Journal of Eastern-European Criminal Law, 1, 208-223.

Blagojević, S., \& Damijan, J. P. (2013). The impact of corruption and ownership on the performance of firms in Central and Eastern Europe. Post-Communist Economies, 25(2), 133-158.

Bogojević, R., \& Skakavac, T. (2018). Corruption as an obstacle to European integrations. Facta Universitatis, Series: Law and Politics, 16(1), 57-67.

Bologna, J., \& Ross, A. (2015). Corruption and entrepreneurship: Evidence from Brazilian municipalities. Public Choice, 165(1-2), 59-77, https://doi. org/10.1007/s11127-015-0292-5

Borošak, M., \& Šumah, Š. (2018). Corruption in Slovenia. Prizren Social Science Journal, 2(3), 6-17.

Brown, D. S., Touchton, M., \& Whitford, A. (2011). Political polarization as a constraint on corruption: A cross-national comparison. World Development, 39(9), 1516-1529, https://doi.org/10.1016/j.worlddev.2011.02.006

Chabova, K. (2017). Measuring corruption in Europe: Public opinion surveys and composite indicators, Quality and Quantity, 51(4), 1877-1900, https://doi. org/10.1007/s11135-016-0372-8

Charron, N. (2016). Do corruption measures have a perception problem? Assessing the relationship between experiences and perceptions of corruption among citizens and experts. European Political Science Review, 8(1), 147-171, https://doi.org/10.1017/s1755773914000447

Cheung, Y. L., Rau, P. R., \& Stouraitis, A. (2012). How much do firms pay as bribes and what benefits do they get? Evidence from corruption cases worldwide. NBER working paper 17981. Cambridge, USA: National Bureau of Economic Research. Retrieved from http://www.nber.org/papers/w17981.pdf, https://doi. org/10.3386/w17981

Collins, J. D., Uhlenbruck, K., \& Rodriguez, P. (2009). Why firms engage in corruption: A top management perspective. Journal of Business Ethics, 87(1), 89-108, https://doi.org/10.1007/s10551-008-9872-3

Coppedge, M., Gerring, J., Knutsen, C.H., Lindberg, S.I., Teorell, J., Altman, D., Bernhard, M., Fish, M.S., Glynn, A., Hicken, A., Lührmann, A., Marquardt, K.L., McMann, K., Paxton, P., Pemstein, D., Seim, B., Sigman, R., Skaaning, S.-E., Staton, J., Wilson, S., Cornell, A., Alizada, N., Gastaldi, L., Gjerlùw, 
H., Hindle, G., Ilchenko, N., Maxwell, L., Mechkova, V., Medzihorsky, J., von Römer, J., Sundström, A., Tzelgov, E., Wang, Y., Wig, T., \& Ziblatt, D. (2020). V-Dem [Country-Year/Country-Date] Dataset v10. Available at Varieties of Democracy (V-Dem) Project. doi: https://doi.org/10.23696/vdemds20, https://doi.org/10.2139/ssrn.3557877

Cuervo-Cazurra, A. (2016). Corruption in international business. Journal of World Business, 51(1), 35-49, https://doi.org/10.1016/j.jwb.2015.08.015

de Jong, E., \& Bohmans, C. (2011). Does corruption discourage international trade? European Journal of Political Economy, 27(2), 385-398, https://doi. org/10.1016/j.ejpoleco.2010.11.005

Dreher, A., \& Gassebner, M. (2013). Greasing the wheels? The impact of regulations and corruption on firm entry. Public Choice, 155, 413-432, https://doi. org/10.1007/s11127-011-9871-2

Elliot, K. A. (1997). Corruption and the global economy. Washington, USA: Institute for International Economics.

Fink-Hafner, D., \& Thomas, C. S. (2019). The Balkan experience: Explanations of public affairs and interest group activity. Journal of Public Affairs, 19(2), e1919, https://doi.org/10.1002/pa.1919

Fisman, R., \& Svensson, J. (2007). Are corruption and taxation really harmful to growth? Firm level evidence. Journal of Development Economics, 83(1), 63-75, https://doi.org/10.1016/j.jdeveco.2005.09.009

$\mathrm{Fu}, \mathrm{X}$. (2012). Foreign direct investment and managerial knowledge Spillovers through the diffusion of management practices. Journal of Management Studies, 49(5), 970-999, https://doi.org/10.1111/j.1467-6486.2011.01036.x

Gamberoni, E., Gartner, C., Giordano, C., \& Lopez-Garcia, P. (2016). Is corruption efficiency-enhancing? A case study of nine Central and Eastern European countries, ECB Working Paper, No. 1950, European Central Bank (ECB), Frankfurt a. M., Germany. Retrieved from https://www.ecb.europa.eu/pub/ pdf/scpwps/ecbwp1950.en.pdf, https://doi.org/10.2139/ssrn.2844729

Glavinja, D., Cerić, A., \& Nahod, M. M. (2017). Corruption in the construction industry: Comparison of survey results in Croatia and the United Kingdom. Paper presented at International Research Conference 2017: Shaping Tomorrow's Built Environment Conference Proceedings, University of Salford, Manchester, UK.

Godoy, S., \& Stiglitz, J. E. (2007). Growth, initial conditions, law and speed of privatization in transition countries: 11 years later. In E. Estrin, G. W. Kołodko \& M. Uvalic (Eds.), Transition and beyond. Essays in bonor of Mario Nuti (pp. 89-117). London, UK: Palgrave Macmillan, https://doi. org/10.1057/9780230590328_5

Grubiša, D. (2010). Anti-corruption policy in Croatia: Benchmark for EU accession. Politička misao, 47(5), 69-95.

Gutmann, J., Padovano, F., \& Voigt, S. (2019). Perception vs. experience: Explaining differences in corruption measures using microdata. Retrieved from http:// dx.doi.org/10.2139/ssrn.2659349, https://doi.org/10.2139/ssrn.2659349 
Habiyaremye, A., \& Raymond, W. (2018). How do foreign firms' corruption practices affect innovation performance in host countries? Industry-level evidence from transition economies. Innovation, 20(1), 18-41, https://doi.org/10.1080/ 14479338.2017.1367626

Hanousek, J., Shamshur, A., \& Trel, J. (2019). Firm efficiency, foreign ownership and CEO gender in corrupt environments. Journal of Corporate Finance, 59(December), 344-360, https://doi.org/10.1016/j.jcorpfin.2017.06.008

Helliwell, J. F. (2006). Well-being, social capital and public policy: What's new? The Economic Journal, 116(510), C34-C45, https://doi.org/10.1111/j.14680297.2006.01074.x

Hellman, J. S., Jones, G., \& Kaufmann, D. (2002). Far from bome: Do foreign investors import bigher standards of governance in transition economies? World Bank Working Paper. Retrieved from https://doi.org/10.2139/ssrn.386900.

Heywood, P. M. (2015). Measuring corruption: perspectives, critiques and limits. In P. M. Heywood (Ed.), Routledge handbook of political corruption (pp. 137-153). London, UK \& New York, USA: Routledge, https://doi. org/10.4324/9781315739175

Huntington, S. P. (1968). Political order in changing societies. New Haven, USA: Yale University Press.

Ivanović-Djukić, M., Lepojević, V., Stefanović, S., van Stel, A., \& Ateljević, J. (2019). Corruption as an obstacle for starting a new business in Serbia. International Review of Entrepreneurship, 17(1), 37-58.

Iriyama, A., Kishore, R., \& Talukdar, D. (2016). Playing dirty or building capability? Corruption and HR training as competitive actions to threats from informal and foreign firm rivals. Strategic Management Journal, 37(10), 2152-2173, https://doi.org/10.1002/smj.2447

Karklins, R. (2005). The system made me do it: Corruption in post-communist societies. New York, USA \& London, UK: M.E. Sharpe, Inc, https://doi. org/10.4324/9781315698939

Kaufmann, D. (1997). Corruption: The facts. Foreign Policy, 107, 114-131.

Knack, S. (2007). Measuring corruption: A critique of indicators in Eastern Europe and Central Asia. Journal of Public Policy, 27(3), 255-291, https://doi. org/10.1017/s0143814x07000748

Krammer, S. M. S. (2013). Greasing the wheels of change: the impact of corruption on firms' innovation in transition economies. Paper presented at the $35^{\text {th }}$ DRUID Celebration Conference 2013, Barcelona, Spain, June 17-19.

Lawrence, P. R., \& Lorsch, J. W. (1967). Organization and environment. Boston, USA: Graduate School of Business.

Ledeneva, A., Bratu, R., \& Köker, P. (2017). Corruption studies for the twenty-first century: Paradigm shifts and innovative approaches. The Slavonic and East European Review, 95(1), 1-20, https://doi.org/10.5699/slaveasteurorev2.95.1.0001

Leff, N. H. (1964). Economic development through bureaucratic corruption. American Behavioral Scientist, 8(3), 8-14, https://doi.org/10.1177/00027642 6400800303 
Luo, Y., \& Han, B. (2009). Graft and business in emerging economies: An ecological perspective. Journal of World Business, 44(3), 225-237, https://doi. org/10.1016/j.jwb.2008.08.006

Martin, K. D., Cullen, J. B., Johnson, J. L., \& Parboteeah, K. P. (2007). Deciding to bribe: A cross-level analysis of firm and home country influences on bribery activity. Academy of Management Journal, 50(6), 1401-1422, https://doi. org/10.5465/amj.2007.28179462

Mauro, P. (1995). Corruption and growth. The Quarterly Journal of Economics, 110(3), 681-712.

Mocan, N. (2008). What determines corruption? International evidence from microdata. Economic Inquiry, 46(4), 493-510, https://doi.org/10.1111/j.14657295.2007.00107.x

Moran, T. H. (2006). How multinational investors evade developed country laws to prevent bribery and corruption in the developing world (Including the US Foreign Corrupt Practices Act) and what can be done about it. Centre for Global Development Working Paper No. 79. Retrieved from https://www.cgdev.org/sites/ default/files/6113_file_WP_79.pdf, https://doi.org/10.2139/ssrn.984044

Nur-tegin, K., \& Jakee, K. (2020). Does corruption grease or sand the wheels of development? New results based on disaggregated data. The Quarterly Review of Economics and Finance, 75, 19-30, https://doi.org/10.1016/j.qref.2019.02.001

Pellegata, A. (2012). Constraining political corruption: an empirical analysis of the impact of democracy. Democratization, 20(7), 1195-1218, https://doi.org /10.1080/13510347.2012.688031

Perlić, B. (2016). Corruption and democratization in post-Communist states: A comparative study of the impact of corruption on democratic institutions in Serbia and Croatia. Retrieved from https://ntnuopen.ntnu.no/ntnu-xmlui/ handle $/ 11250 / 2419665$ ?locale-attribute $=$ no

Popova, M., \& Post, V. (2018). Prosecuting high-level corruption in Eastern Europe. Communist and Post-Communist Studies, 51(3), 231-244, https://doi. org/10.1016/j.postcomstud.2018.06.004

Potrafke, N. (2019). Electoral cycles in perceived corruption: International empirical evidence. Journal of Comparative Economics, 47(1), 215-224, https://doi. org/10.1016/j.jce.2018.11.003

Safavian, M., Graham, D., \& Gonzalez-Vega, C. (2001). Corruption and microenterprises in Russia. World Development, 29(7), 1215-1224, https://doi. org/10.1016/s0305-750x(01)00036-5

Sandholtz, W., \& Taagepera, R. (2007). Corruption, culture, and communism. International Review of Sociology: Revue Internationale de Sociologie, 15(1), 109131, https://doi.org/10.1080/03906700500038678

Schneider, F., \& Enste, D. H. (2000). Shadow economies: Size, causes and consequences. Journal of Economic Literature, 38(1), 77-131, https://doi. org/10.1257/jel.38.1.77

Sekulić, D. (2010). Perceptions of corruption over time, corruption and trust. Zagreb, Croatia: Centre for Democracy and Law Miko Tripalo 
Shleifer, A., \& Vishny, R.W. (1993). Corruption. The Quarterly Journal of Economics, 108(3), 599-617, https://doi.org/10.2307/2118402

Sundaram, A. K., \& Black, J. S. (1992). The environment and internal organization of multinational enterprises. Academy of Management Review, 17(4), 729-757, https://doi.org/10.5465/amr.1992.4279065

Sotiropoulos, D. A. (2017). Corruption, anti-corruption and democracy in the Western Balkans. Političke perspektive, 7(3), 7-26.

Svensson, J. (2003). Who must pay bribes and how much? Evidence from a cross section of firms. Quarterly Journal of Economics, 118(1), 207-230, https://doi. org/10.1162/00335530360535180

Svensson, J. (2005). Eight questions about corruption. Journal of Economic Perspectives, 19(3), 19-42, https://doi.org/10.1257/089533005774357860

Ullah, B. (2020). Financial constraints, corruption, and SME growth in transition economies. The Quarterly Review of Economics and Finance, 75, 120-132, https://doi.org/10.1016/j.qref.2019.05.009

Vaughan, D. (1999). The dark side of organizations: Mistake, misconduct, and disaster. Annual Review of Sociology, 25, 271-305, https://doi.org/10.1146/ annurev.soc.25.1.271

Vuković, V. (2017). The political economy of local government in Croatia: Winning coalitions, corruption, and taxes. Public Sector Economics, 41(4), 387420, https://doi.org/10.3326/pse.41.4.1

Wadsworth, F. H., Wheat, J., \& Swartz, B. (2012). Balkan corruption perception: Impediments to competitive activity in Bosnia-Herzegovina, Croatia, FYROM, Serbia/Montenegro, and Slovenia. International Business \& Economics Research Journal, 11(7), 731-744, https://doi.org/10.19030/iber.v11i7.7060

Wallace, S., \& Latcheva, R. (2006). Economic transformation outside the law: Corruption, trust in public institutions and the informal economy in transition countries of Central and Eastern Europe. Europe-Asia Studies, 58(1), 81-102, https://doi.org/10.1080/09668130500401707

Wellalage, N. H., Locke, S., \& Samujh, H. (2019). Corruption, gender and credit constraints: Evidence from South Asian SMEs. Journal of Business Ethics, 159(1), 267-280, https://doi.org/10.1007/s10551-018-3793-6

The World Bank Group (1997). Helping countries combat corruption: The role of the World Bank. Retrieved from http://www1.worldbank.org/publicsector/anticorrupt/corruptn/cor02.htm\#note1

Williams, C. C., Martinez-Perez, A., \& Kedir, A. (2016). Does bribery have a negative impact on firm performance? A firm-level analysis across 132 developing countries. International Journal of Entrepreneurial Behavior \& Research, 22(3), 398-415, https://doi.org/10.1108/ijebr-01-2016-0002 


\section{Appendix}

Table A1: Sample size of the BEEPS

\begin{tabular}{|l|c|c|c|}
\hline & Croatia & Serbia & Slovenia \\
\hline 2002 & 187 & 230 & 188 \\
\hline 2005 & 236 & 282 & 223 \\
\hline 2013 & 360 & 360 & 270 \\
\hline 2019 & 404 & 361 & 409 \\
\hline
\end{tabular}

Source: Author based on the BEEPS dataset, various waves.

Table A2: Perceived percentage of contract value in the form of informal payment

\begin{tabular}{|l|c|c|c|c|c|}
\hline \multirow{2}{*}{ Croatia } & & 2002 & 2005 & 2013 & 2019 \\
\cline { 2 - 6 } & Min & 1 & 0.1 & 3 & 5 \\
\hline \multirow{2}{*}{ Serbia } & Max & 20 & 20 & 15 & 5 \\
\cline { 2 - 6 } & Max & 0.1 & .2 & 2 & 1 \\
\hline \multirow{2}{*}{ Slovenia } & Min & 1 & 15 & 8 & 20 \\
\cline { 2 - 6 } & Max & 20 & 20 & 20 & 15 \\
\hline
\end{tabular}

Source: Author based on the BEEPS dataset, various waves.

Table A3: Probability that a firm will engage in petty corruption

\begin{tabular}{|c|c|c|c|}
\hline Variables & Croatia & Serbia & Slovenia \\
\hline Firm age & $\begin{array}{c}-0.0324^{* *} \\
(0.0139) \\
\end{array}$ & $\begin{array}{c}0.00332 \\
(0.00386)\end{array}$ & $\begin{array}{c}-0.00486 \\
(0.00708)\end{array}$ \\
\hline \multicolumn{4}{|l|}{ Firm size (vs. medium) } \\
\hline -small & $\begin{array}{c}-0.126 \\
(0.426)\end{array}$ & $\begin{array}{l}-0.438^{*} \\
(0.241)\end{array}$ & $\begin{array}{l}-0.0845 \\
(0.415)\end{array}$ \\
\hline -large & $\begin{array}{c}-0.481 \\
(0.537)\end{array}$ & $\begin{array}{l}-0.510 \\
(0.332)\end{array}$ & $\begin{array}{c}0.678 \\
(0.488)\end{array}$ \\
\hline Firm with foreign ownership & - & $\begin{array}{r}-0.0200 \\
(0.369)\end{array}$ & $\begin{array}{c}0.515 \\
(0.364)\end{array}$ \\
\hline
\end{tabular}




\begin{tabular}{|c|c|c|c|}
\hline Exporter & $\begin{array}{l}-0.251 \\
(0.544)\end{array}$ & $\begin{array}{c}0.428 \\
(0.273)\end{array}$ & $\begin{array}{l}-0.699^{*} \\
(0.368)\end{array}$ \\
\hline Firm investing in $\mathrm{R} \& \mathrm{D}$ & $\begin{array}{c}1.316^{* * *} \\
(0.492)\end{array}$ & $\begin{array}{l}-0.147 \\
(0.295)\end{array}$ & $\begin{array}{l}0.0660 \\
(0.270)\end{array}$ \\
\hline Manager's experience & $\begin{array}{l}-0.00990 \\
(0.0139)\end{array}$ & $\begin{array}{c}0.00255 \\
(0.00957)\end{array}$ & $\begin{array}{c}-0.0320^{* *} \\
(0.0142)\end{array}$ \\
\hline Firm with female owners & $\begin{array}{c}-0.00875 \\
(0.387)\end{array}$ & $\begin{array}{c}0.188 \\
(0.246)\end{array}$ & $\begin{array}{c}0.167 \\
(0.378)\end{array}$ \\
\hline Firm with a female manager & & $\begin{array}{c}0.148 \\
(0.291)\end{array}$ & \\
\hline \multicolumn{4}{|l|}{ Sector (vs. manufacturing) } \\
\hline -retail & $\begin{array}{l}-0.182 \\
(0.709)\end{array}$ & $\begin{array}{c}0.563 \\
(0.348)\end{array}$ & - \\
\hline -wholesale & $\begin{array}{c}0.658 \\
(0.821)\end{array}$ & $\begin{array}{l}0.857^{* *} \\
(0.362)\end{array}$ & - \\
\hline -construction & $\begin{array}{l}-0.214 \\
(0.771)\end{array}$ & $\begin{array}{c}0.803^{* *} \\
(0.404)\end{array}$ & - \\
\hline -service & - & $\begin{array}{c}0.396 \\
(0.392)\end{array}$ & $\begin{array}{c}0.422 \\
(0.322)\end{array}$ \\
\hline Firm having informal competitors & $\begin{array}{l}1.339 * * * \\
(0.510)\end{array}$ & $\begin{array}{c}0.213 \\
(0.235)\end{array}$ & - \\
\hline $\begin{array}{l}\text { Manager time dealing with public } \\
\text { officials }\end{array}$ & $\begin{array}{r}0.0248^{* * *} \\
(0.00758)\end{array}$ & $\begin{array}{c}0.0113 \\
(0.00795)\end{array}$ & $\begin{array}{r}-0.00714 \\
(0.0139)\end{array}$ \\
\hline Firms with a government contract & $\begin{array}{l}-0.901 \\
(0.780)\end{array}$ & $\begin{array}{l}0.0750 \\
(0.263)\end{array}$ & $\begin{array}{c}0.312 \\
(0.411)\end{array}$ \\
\hline $\begin{array}{l}\text { Firm manager politically elected or } \\
\text { appointed }\end{array}$ & $\begin{array}{c}2.127^{* * *} \\
(0.564)\end{array}$ & $\begin{array}{c}0.202 \\
(0.534)\end{array}$ & - \\
\hline Constant & $\begin{array}{c}-2.160^{* *} \\
(1.101)\end{array}$ & $\begin{array}{c}-2.302^{* * *} \\
(0.450)\end{array}$ & $\begin{array}{c}-1.442^{* * *} \\
(0.521)\end{array}$ \\
\hline Observations & 220 & 296 & 146 \\
\hline Pseudo R2 & 0.335 & 0.0971 & 0.183 \\
\hline Log-likelihood & -18.32 & -66.10 & -14.99 \\
\hline Correctly classified & 97.73 & 93.24 & 97.26 \\
\hline Pearson chi2 & 102.81 & 286.7 & $164.7^{* *}$ \\
\hline Hosmer-Lemeshow & 1.01 & 7.23 & 10.37 \\
\hline
\end{tabular}

Source: Author's estimates based on BEEPS 2019.

Robust standard errors in parentheses. *** denotes significance at $1 \%,{ }^{* *}$ at $5 \%$ and * at $10 \%$. 


\title{
MANAGERS' PERCEPTION OF CORRUPTION IN CROATIA, SERBIA AND SLOVENIA
}

\begin{abstract}
Summary
The paper provides a comparative analysis of managers' perception of corruption in three post-transition economies based on The World Bank Enterprise Survey data in the period 2002-2019. Results suggest that although the main forms of corruption seem to differ among the countries, there does not seem to be any systemic change within individual countries. While in Slovenia managers are most likely to notice grand corruption, petty corruption seems to be more widespread in Croatia and Serbia. Those who perceive corruption to be bigher on the power ladder are also the ones more likely to consider it an obstacle for their business endeavours. The difference is the most significant in Croatia, suggesting that additional efforts to reduce corruption would be most readily welcomed by the business sector in that country. Limitations of the present study rely on the quality of the data source used. While there is no doubt that the survey has been carried out with the highest quality standards, the potential strategic answering of respondents can hardly be avoided when it comes to such an illusive phenomena as corruption. A possible remedy could be to supplement the results with a similar survey that would focus on questions specific to corruption practices of the analysed countries.
\end{abstract}

Keywords: corruption, managers' perception, Croatia, Serbia, Slovenia, comparative analysis 


\section{MENADŽERSKA PERCEPCIJA KORUPCIJE U HRVATSKOJ, SRBIJI I SLOVENIJI}

\section{Sažetak}

$U$ radu je provedena usporedna analiza menadžerske percepcije korupcije $u$ tri post tranzicijske ekonomije temeljem podataka iz Ankete poduzeća Svjetske banke u razdoblju 2002.-2019. Rezultati upućuju na zaključak da unatoč tome što se glavni oblici korupcije izgleda razlikuju medu promatranim zemljama, unutar svake od njib čini se nema sistemske promjene. Dok u Sloveniji menadžeri uglavnom primjećuju veliku korupciju, sitna je korupcija raširena u Hrvatskoj i Srbiji. Menadžeri koji imaju snažniju percepciju korupcije su ujedno oni koji tendiraju smatrati ju zaprekom njibovim poduzetničkim nastojanjima. Razlika je najveća u Hrvatskoj, što sugerira da bi dodatni napori uloženi u smanjenje korupcije vjerojatno bili najviše pozdravljeni od strane brvatskog poslovnog sektora. Ograničenja ovog rada uglavnom leže u kvaliteti korištenih podataka. Premda nema dvojbe da je anketa provedena uz poštovanje najboljib standarda kvalitete, potencijalno strateško odgovaranje ispitanika nemoguće je izbjeći kod istraživanja tako varljivog koncepta kao što je korupcija. Ta bi se manjkavost mogla popraviti provedbom slične dodatne ankete koja bi se usredotočila na specifična pitanja o koruptivnoj praksi u analiziranim zemljama. Ključne riječi: korupcija, menadžerska percepcija, Hrvatska, Srbija, Slovenija, usporedna analiza 